\title{
FOREWORD | Away from Dūra (or Life in the Margins)
}

\author{
Salim Tamari
}

Sāmī 'Amr's mandate-era memoirs of his days working for the British in Palestine in the 1940s provides us with a rare intimate window into the world of thousands of Palestinians who flocked from their villages and provincial towns during the crucial years between the two great wars to seek employment opportunities and social advancement in the British Mandate capital of Jerusalem. With village origins in Dūra, one of the most conservative and "tribal" strongholds of Jabal al-Khalīl, Sāmī grew up in the city of Hebron but set out to make his way in life in the city of Jerusalem.

The central theme of this diary of self-discovery is the tortuous search for a Palestinian modernity that is both Arab and Islamic. In this search the author seems to be fighting the ghosts of his own society-what he identifies as the repressive traditionalism of the village and the tribalism of Mt. Hebron. In this he has internalized a Europeanized colonial image of Arab backwardness, along with a view of progress in a model of emancipation that is anchored in adopting a dress code, mannerisms, and a normative code of behavior derived from the European adversary. Yet 'Amr's view of social emancipation via British rule is conflicted by the author's own experience of the mandate as a repressive colonial apparatus, especially during the various upheavals that accompanied British rule, his brother's imprisonment by the authorities, andnot least—by his perpetual, but frustrated, search for the Perfect Woman.

In seeking employment within the ranks of the British institutions in Palestine and civil service (in Sāmì's case with NAAFI, in his brother's case with the military) 'Amr was following in the footsteps of his countrymen from the Ottoman period, when thousands of city folks filled the ranks of the civil service, and hundreds of thousands volunteered or were conscripted to fight in the imperial armies of the sultan. Quite a few nationalist figures, like Muḥammad 'Izzat Darwaza, Sa'dun al-Hușari, and Rustum Haydār, wrote proudly of their civil and military service in the imperial bureaucracy. They often saw it as an essential schooling in acquiring necessary skills for the nationalist struggle. The same is true of the early employment in the British police, army, and civil service, when thousands of Palestinians, and other Arabs serving in the service of the British and French Mandates, saw this ser- 
vice as a legitimate source of employment which also fulfilled their national duty by preparing the ground for the period of postcolonial independence. In the case of employment in the British armed forces in Palestine, however, the situation began to differ in the thirties and forties in several facets. First the incorporation of the terms of the Balfour Declaration into the British Mandate made it difficult for most Palestinians to believe that their future was similar to the situation in Syria, Lebanon, Iraq, or Transjordan-where local parliaments, representative government, and the rubric of statehoods were being implemented. The Palestinian Arabs were compelled to contest appointments in the public sector, to challenge budget allocations, and to vie for the land itself, as it was being colonized by the Zionist project. Second, the Rebellion of 1936-1939-witnessed by 'Amr and his family a few years before 'Amr began writing his diary-had a major impact on every feature of daily life and was a constant reminder to those who chose to serve in the ranks of the colonial state apparatus that theirs was not a neutral or innocent employment.

Kimberly Katz reminds us of the pitfalls of serving the British in this troubled period. In 1936 the British army created the Palestine Battalion of the Buffs to fight Arab rebellion. Its recruits were both Jews and Arabs, the latter mostly of peasant origin. In 1942 that battalion was expanded to prepare for native participation in the struggle against the Axis powers. At its peak, 27,000 Palestinians volunteered as official soldiers in the ranks of the British Army. Of those, one-third-about 9,000 soldiers-were Palestinian Arab; the rest were Jewish recruits. As the war operations extended to the Middle East, most notably in North Africa and the Palestinian coast, their numbers increased considerably. What is astounding about these figures is that the number of Palestinian fighters in the colonial forces, if one also includes Arab members of the colonial police force and Criminal Investigation Department (CID), equaled, if not exceeded, the combined forces of resistance groups, including the militias of al-Jihād al-Muqaddas (Husseini leadership), the Qassāmites (followers of Sheikh 'Izz al-Dīn al-Qassām) and the Arab Salvation Army (al-Qāwuqjī).

It was this army that Sāmī's brother, Sa'dī, joined in the early 1940 s, to Sāmī's great embarrassment. It is not clear from the diary, however, whether this embarrassment was caused by his brother's very act of joining the colonial army, by his going AWOL when he was posted to the Egyptian front, or-possibly_by his escape from the increasing danger of having to fight against Rommel's forces in the Libyan desert. The ambivalence in 'Amr's diary 
on this issue is intentional. It extends itself not only to his brother's army career and his own service in the NAAFI, but also to his silence, or ambiguity, on the burning issues of the period-in particular the Arab Revolt and the Zionist Question. While displaying a considerable amount of patriotism reflected in his love of the land, and showing concern that high levels of immigration were likely to undermine the possibility of independence for Arab Palestine, 'Amr chose not to compromise his standing by joining any oppositional movement or by expressing these sentiments in any coherently anticolonial manner.

In my reading of the diary, this ambivalence is not necessarily a mark of cowardice on the part of the writer. (He is certainly openly critical of his own community's traditionalism and "backwardness"-a position which would have required a considerable defiance of his own society.) Nor does it seem to emanate from fear of losing his job. At the heart of 'Amr's hesitancy seems to lie a quest for a defiant, modernist Palestine which, in his view, required a struggle that transcended Zionism and colonialism. Such a struggle required a radical encounter with the challenges of Western culture, in which the mandate authority was itself an instrument of this modernity. We notice such obsessions on 'Amr's part by his references to colonial work discipline, dress codes, unveiling, industrial organizing, and modern farming techniques as the appropriate conditions for the uplifting of Palestine. In his fascination with colonial modernity, 'Amr was not alone-he joins a notable series of writers from this period that include Khalidah Adib (Halide Edip), Khalīl Totah, Khalīl as-Sakakini, and 'Umar al-Barghoutī. His dilemma lies in his inability to combine an image of emancipated modernity with an anticolonial perspective.

'Amr's diary is an important addition to a new genre of biographic narratives of Palestinian and Arab figures that have appeared in the last decade, in which the personal experience of the narrator highlights unexamined features in the social history of the Ottoman and colonial periods. The distinctive feature of these subaltern narratives is that they invariably belong to non-elite groups-thus throwing new light on major transformations in society-and, more importantly, they are informed by conceptual paradigms that render them important tools in understanding the shifts and ruptures that occurred after World War I in the Arab East. Those ruptures include the nature of urban modernity in the Middle East, the manner in which the state and the colonial civil service constituted a basic instrument of socialization in the public sphere, and the redefinition of the relations between men and women who increasingly sought employment in the public sector. 
Kimberly Katz was able, through her skillful editing and framing of this diary, to steer through this tortuous route of 'Amr's self-reflections without passing judgment on his motivations or his political predicament. In doing so she has provided us with an interpretation of the diary in the context of his time, permitting the reader to appreciate why he wrote these utterances, and their meaning for the postwar generation. 